\title{
COMUNICACÕES
}

\section{Colletotrichum gloeosporioides em frutos de juçara (Euterpe edulis) na Mata Atlântica, em Paraty-RJ e Ubatuba-SP}

\author{
Tathianne Pastana de Sousa Poltronieri ${ }^{1}$; Luís Antônio Siqueira de Azevedo ${ }^{1}$; Jaqueline Rosemeire Verzignassi²; \\ Diene Elen Miranda da Silva ${ }^{1}$
}

\begin{abstract}
${ }^{1}$ Departamento de Fitopatologia e Entomologia, Instituto de Biologia, Universidade Federal Rural do Rio de Janeiro, CEP 23890-000, Rio de Janeiro, Seropédica, RJ. 2012. ²Embrapa Gado de Corte, Avenida Rádio Maia, 830, CEP 79106-550, Campo Grande. MS.

Autor para correspondência: Tathianne Pastana de Sousa Poltronieri (tathianne_pastana@hotmail.com)

Data de chegada: 18/09/2013. Aceito para publicação em: 10/02/2014.
\end{abstract}

A palmeira juçara (Euterpe edulis Mart.) é uma das espécies nativas mais importantes da Mata Atlântica, encontrando-se na lista das espécies da flora ameaçadas de extinção e apresentando grande potencial ecológico e econômico. Tradicionalmente essa palmeira era utilizada apenas para a produção de palmito. Recentemente, porém, maior atenção tem sido dada ao potencial de seus frutos para a produção de polpa, analogamente aos frutos do açaizeiro (Euterpe oleracea), produzido na Amazônia. Ainda que exista literatura sobre a palmeira, contemplando a ecologia da espécie e seu manejo para produção de palmito, são escassos os estudos sobre as doenças, especificamente aquelas que infectam os seus frutos. Do final de fevereiro até início de julho de 2012, nas localidades de Camburi, Corcovado, Praia Almada e Praia Brava, entre as cidades de Paraty - RJ e Ubatuba - SP, foram realizadas coletas de frutos com sintomas de antracnose, além de frutos sadios (Figuras 1A a 1C). As amostras foram encaminhadas para análise no Laboratório de Fitopatologia da Universidade Federal Rural do Rio de Janeiro (UFRRJ). Para isolamento do patógeno, os frutos com sintomas foram lavados com água corrente e sabão e, posteriormente, enxutos com papel toalha estéril. Fragmentos foram retirados da área de transição da lesão com o tecido sadio, desinfestados com álcool (70\%) por 30 segundos, transferidos para placas de Petri com hipoclorito de sódio $(1,5 \%)$ por 2 minutos e lavados duas vezes em água destilada e esterilizada. Os fragmentos foram transferidos para placas de Petri contendo meio de cultura BDA sintético (Batata-Dextrose-Ágar), incubadas em câmaras de crescimento (BOD) a $25^{\circ} \mathrm{C}$ por 10 dias. Todos os isolados apresentaram micélio bastante ramificado, septado e hialino, apresentando acérvulos sem a presença de setas e conídios hialinos, com uma célula, predominantemente oblongos, com ápices arredondados. De acordo com as características morfológicas e culturais apresentadas, o fungo foi identificado como Colletotrichum gloeosporioides Penzig Saccardo (Figura 1D). Adicionalmente, quatro isolados, um de cada localidade, foram enviados para a Universidade Federal de Pernambuco, onde foram submetidos à análise molecular, por PCR, com marcadores ITS4 específicos para C. gleosporioides e Colletotrichum acutatum, bem como os marcadores para a $\beta$-tubulina, específicas também para as duas espécies. Os marcadores utilizados indicam que o isolado em questão tratava-se de C. gloeosporioides, pois apresentou bandas nos dois marcadores específicos a esta espécie
(ITS4 e $\beta$-tubulina) (Figura 1E). Adiciona-se que não houve marcação de bandas para os primers para C. acutatum (Figura 1E). Com o objetivo de comprovar a patogenicidade, culturas monospóricas foram obtidas. Para tanto, as colônias foram repicadas para tubos de ensaio com BDA e, após incubação por sete dias em câmaras de crescimento a $25^{\circ} \mathrm{C}$, foram feitas suspensões de conídios, que foram riscadas em placas com meio BDA. Cada um dos quatro isolados foi inoculado em 20 frutos sadios, de forma que discos de micélio + meio de cultura com 7 $\mathrm{mm}$ de diâmetro foram depositados na superfície de cada fruto. Após a inoculação, os frutos foram colocados em câmara úmida de vidro, por $72 \mathrm{~h}$ em temperatura ambiente $\left(30^{\circ} \mathrm{C}\right.$ e $\left.90 \% \mathrm{UR}\right)$ para a incubação. Como testemunha foram considerados 20 frutos não inoculados, também submetidos à câmara úmida. Após três dias da inoculação, os primeiros sintomas de antracnose surgiram nos frutos inoculados, ou seja, lesões com pontuações de coloração marrom progredindo para manchas necróticas, algumas vezes deprimidas, de coloração preta (Figura 1F), reproduzindo os sintomas encontrados nos frutos colhidos. Cada um dos isolados foi inoculado, também, em 15 frutos de açaí (Euterpe oleraceae), produzidos na região de Belém (PA). A incubação foi efetuada da mesma forma que para os frutos de juçara e, como testemunha, foram considerados 15 frutos. Os frutos apresentaram os mesmos sintomas descritos para os frutos de juçara inoculados. Além disso e com o objetivo de avaliar o efeito do fungo na germinação, 50 frutos de juçara sadios foram inoculados com cada isolado, considerando-se, como testemunha, 50 frutos não inoculados. Esses frutos foram colocados para germinar em areia lavada contida em caixa tipo gerbox e mantidos em casa de vegetação e considerou-se a média do número de plantas estabelecidas ao final de 90 dias. Apenas 14,8\% dos frutos inoculados com o fungo formaram plantas ao final de 90 dias e, na testemunha não inoculada, $40 \%$ das plantas foram formadas ao final do período. Ressaltam-se que as plantas que conseguiram se estabelecer, provenientes de frutos inoculados, não apresentaram qualquer sintoma de antracnose. Assim, C. gloeosporioides não apenas provocou sintomas de antracnose nos frutos, mas influenciou negativamente a germinação das sementes provenientes dos frutos infectados. Este é o primeiro relato de Colletotrichum gloeosporioides causando antracnose em frutos de juçara na Mata Atlântica. 


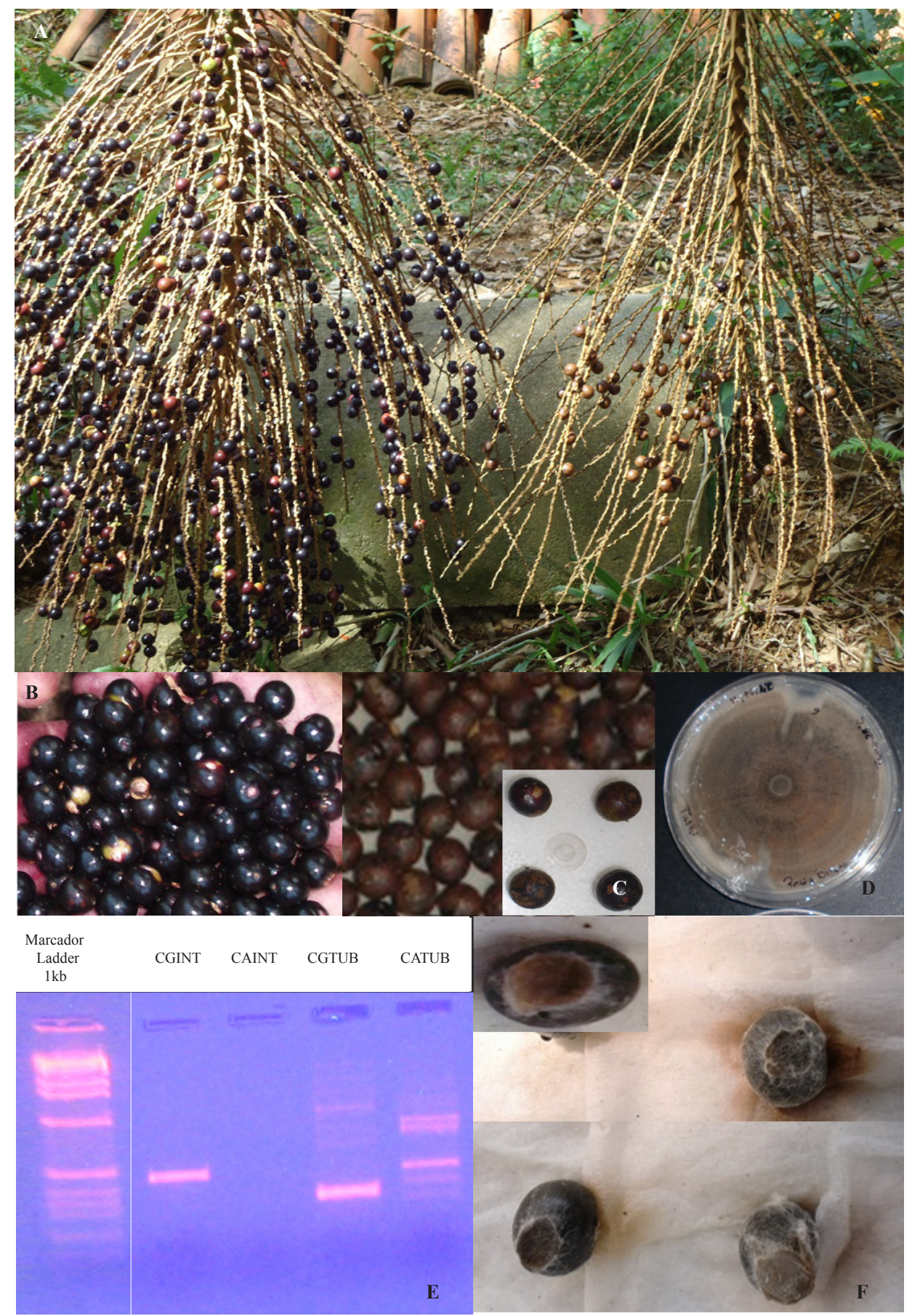

Figura 1. Cacho de frutos de juçara sadios e cacho com sintomas de antracnose (A). Frutos sadios e com sintomas (B e C); no detalhe, frutos necrosados. Colônia de Colletotrichum gloeosporioides obtida de frutos com antracnose(D). Gel de eletroforese, com marcadores ITS4 específicos para C. gleosporioides e C. acutatum respectivamente CGINT e CAINT, bem como os marcadores para a $\beta$-tubulina, específicas também para as duas espécies seguindo a mesma ordem CGTUB E CATUB, respectivamente para C. gloeosporioides e C. acutattum (E). Frutos de juçara inoculados com C. gloeosporioides e apresentando sintomas da doença (F). 